\title{
The Dynamics of Rejang Renteng Dance in Bali as an Intangible Cultural Heritage of the World
}

\author{
I Nyoman Linggih ${ }^{\dagger}$ and I Ketut Sudarsana ${ }^{+*}$
}

\section{Abstract}

This current study is intended to interpret a Balinese cultural product which has taken root in and connected to the Hindu religious system, namely the Rejang Renteng dance. Apart from becoming a cultural product, it also functions as a social cohesion as it involves a significant number of dancers who are children, women, elderly people and the homemakers who become the members of an organisation known referred to as PKK (Family Welfare Education). They interact with one another. The growth and development of the dance have been used as the icon of every Hindu religious activity in Bali, and also as an icon of different social activities. The question is why the Rejang Renteng dance has developed more rapidly than the other dance forms. This current study is also intended to answer different matters on the Rejang Renteng dance, which cannot be separated from the dynamics of the development of the Balinese society which is changing in the current globalisation era. It is also intended to explore the shift in its meaning, function and, which has taken place from the beginning until the current times. The current study was conducted at Masceti Temple Gianyar, Karangasem and Denpasar. The qualitative method, especially the observation, interview and documentary techniques, were applied to collect the data. The data were analysed through four steps; they are reduction, classification, interpretation and conclusion drawing. The informants were determined using the purposive method as they had been determined based on their capacities.

The result of the study shows that (1) the Rejang Renteng dance (Rente) can only be performed by the women attaining menopause and are appointed by what is locally referred to as Ida Betara (the God who resides at the temple where the dance is performed) and may not be replaced by others; (2) a purification ceremony is held for the dance; therefore, it is classified as a sacred dance locally referred to as Tari Wali; (3) the Rejang Renteng dance (Rerejangan), which is seasonally performed, is referred to as the Balih-balihan dance; it is a result of the creative reconstruction made by the artists who were inspired by the sacred Rejang dance (Tari Wali). It is massively performed by the women who are the members of the PKK organisation for which no purification ceremony is held. Being a sacred dance, the Rejang Renteng dance is only performed at the temples or the other holy places; however, the creatively reconstructed Rejang Renteng dance can be performed as a part of different religious and social activities. Symbolically, it is a cosmic dance which refers to the concept of the event when the angels descend from the heaven to watch the ritual performed by human beings and is performed in the formation of a circle (renteng). Its sacred meaning empties into the concept of satyam (the truth), siwam (holiness), and sundaram (beauty).

Keywords: Dynamics of the Rejang Renteng dance, Intangible Cultural Heritage, Bali

\footnotetext{
+ Universitas Hindu Negeri I Gusti Bagus Sugriwa Denpasar, Bali, Indonesia

${ }^{*}$ Corresponding Author, Email: ulakan82@gmail.com

(C) 2020 Linggih \& Sudarsana. This is an Open Access article distributed under the terms of the Creative Commons Attribution License (http://creativecommons.org/licenses/by/2.0), which permits unrestricted use, distribution, and reproduction in any medium, provided the original work is properly cited.
} 


\section{Introduction}

The rapid development of the technology of information is one of the factors causing people to be dynamic. As a result, people should adjust themselves to different changes. Several values which are currently established will tend to change, leading to psychological restlessness and crisis of identity (Frosh, 1991:12). Apart from that, traditions will change qualitatively; in other words, the levels of traditions, concepts and symbols change; certain values are added, and the others are discarded (Sztompka, 2007: 72). Cultural expressions and the functions of different institutions may also change resulting from stimulations and the introduction of new concepts from inside and outside societies (Sedyawati, 2010: 383). Besides, the art aspect, as an element of the Balinese culture, which is highly related to the Hindu religious ceremonies, especially those held in Bali, also changes. This is affirmed by Bandem (in Yasa, 2018:1), that in Bali no religious ceremonies can be stated to have been completed without any performing art. One of the dances which cannot be separated from the Hindu religious ceremonial system in Bali is the Rejang dance.

As an attempt to maintain the Rejang dance as an intangible cultural product, it was determined to be an Indonesian Intangible Cultural Heritage by the Minister of Education and Culture of the Republic of Indonesia on 20 October 2015 with the registration number 85149/MPK.E/Da/2015. Suteja claims that nine Balinese dances were determined as the World's Intangible Cultural Heritages on 2 December 2015 in Windhoek, Namibia by UNESCO (the United Nations Educational, Scientific and Cultural Organization) (Suteja, $2017: 1$ ). They were divided into three genres of the Traditional Dances in Bali. They are:

- The Sacred dances (Tari Wali) which include Rejang dance, Dadari dance and Baris Upacara dance;

- The Semi Sacred dances (Tari Bebali) which include Sidhakarya Mask dance, Gambuh Dance Drama and Wayang Wong Dance Drama;
- The Amusement dances (Tari BalihBalihan) (Legong Kraton dance, Joged Bumbung dance and Barong Ket "Kuntisraya" dance).

The appreciation mentioned above causes the dynamics of the Rejang Renteng dance to be urgently discussed so that different problem linked to its changes can be explained to the world - that its meaning is still highly valuable within the Hindu cultural and religious values embedded in the concepts of Satyam (the truth), Siwam (holiness) and Sundaram (beauty) (Dharma Suteja, 2017:1). Indeed, it has already had the Act No. 5 of 2017 concerning cultural furtherance as its juridical foundation. The question is should the Rejang Renteng dance, as a sacred dance, only be performed at the temples? One has to keep in mind that the Rejang Renteng dance has tended to have developed into a folk dance which can be performed everywhere for different activities.

As stated above, the Rejang Renteng dance, also known as the Rejang Dewa dance, as a sacred dance of Bali is concerned it is commonly performed by young girls or women who do not menstruate, and according to the Balinese peoples' belief, they are religioiusly purified. Although they are religiously purified, they are obliged to take part in the ritual referred to as the majaya-jaya ritual in which they are supposed to do a religious activity known as natab banten prayascita, tebasan durmanggala, and byukaonan. This type of Rejang dance is usually performed by nine dancers or an odd number of dancers.

Recently, the forms of the Rejang Renteng dance have been re-developed; one of its forms is that it has been performed by a great number of homemakers who are members of the PKK organization and are not religiously purified; in other words, it has massively been performed, and the dancers do not necessarily involve in the religious activity mentioned above. No purification ritual is performed for them. This form of the Rejang Renteng dance has been developed in almost every traditional neighbourhood unit (banjar) in Bali. Why has 
this taken place? It does not function to welcome and direct (penuntun and pemendak) the Gods who desecend to the earth. It has been voluntarily performed as a part of the temple festival to amuse those who are present at the temple festival. Apart from that, it has also been performed to commemorate the anniversary of the Independence Day of Bali, the anniversary of the establishment of the young people's organisation, the anniversary of the establishment of a city, and to welcome the Governor, Regent, Political figure who come before the general election is held. The form which is performed by the homemakers, does not symbolise the angels coming from heaven. They voluntarily perform it to amuse themselves after being busy with the household chores. Why has this been performed enthusiastically and massively? It is this phenomenon which needs to be explored scientifically.

The study begins with a brief description of the research method. Following this, the results of the study are critically analysed and discussed.

\section{Research Method}

The key aim of the study was to explore the dyanmics of Rejang Renteng dance in Bali as an intangible cultural heritage of the world. For this, three theories were used to analyse the forms, functions and the meaning of the Rejang Renteng dance. The religious theory was used to analyse how the religious system is used as the foundation of the dance; the structuralfunctional theory was used to analyse the extent to which the dance is bound to Hinduism, and theory of aesthetics was used to analyse the dance as an art entity. The study was conducted at Masceti Temple Gianyar, Karangasem and Denpasar. The qualitative method, especially observation, interview and documentary techniques, were used to obtain the data. The data were analysed through reduction, classification, interpretation and conclusion drawing. The purposive model was used to determine the informants as they had been determined based on their capacities.
The approach used in the current study is the phenomenological approach in which how human beings construct important meanings and concepts in the framework of intersubjectivity is interpreted. Phenomenology assumes that human being actively interprets her/his experiences and tries to understand the world using her/his personal experiences (Littlejohn, 2009 : 57). The phenomenon of the Rejang Renteng dance reflects a dependent reality as its meaning needs further interpretation. The following section discusses the results:

\section{Results and Discussion}

\section{Form and Procession of the Rejang Renteng dance}

The form and procession of the Rejang Renteng dance refer to the concepts of (1) Satyam, namely the structure of how truly the art product is produced; (2) Siwam, namely the process or form of the purification of the art product; (3) Sundaram, the form of the art product which can be enjoyed from the viewpoint of its beauty (Granoka, 1998: 15). The anthology of the sacred Rejang Renteng dance was adopted from mamungkah, ngenteg linggih, mapadanan, mapadudusan agung, prayascita bumi and ngusaba nini religious ceremonies held at Masceti Temple, Sayan Village, Ubud, Gianyar, Bali, and the Betara Turun Kabeh religious ceremony held at Besakih. The form and procession of the Rejang Renteng dance were the one performed by the housewives and as stated above, they were the members of the PKK organisation. And as per the protocol of the dance form, the performers were the older women attaining menopause. These women belong to Suana village, Nusa Penida district, Klungkung Regency, Bali.

Among the young performers of Rejang Renteng dance (Rejang Dewa), there were nine girls (an odd number of dancers) who had not attained puberty. As can be seen from Figure 1, it was performed to welcome the God (Ida Betara) residing at the middle yard of the Masceti Temple. 


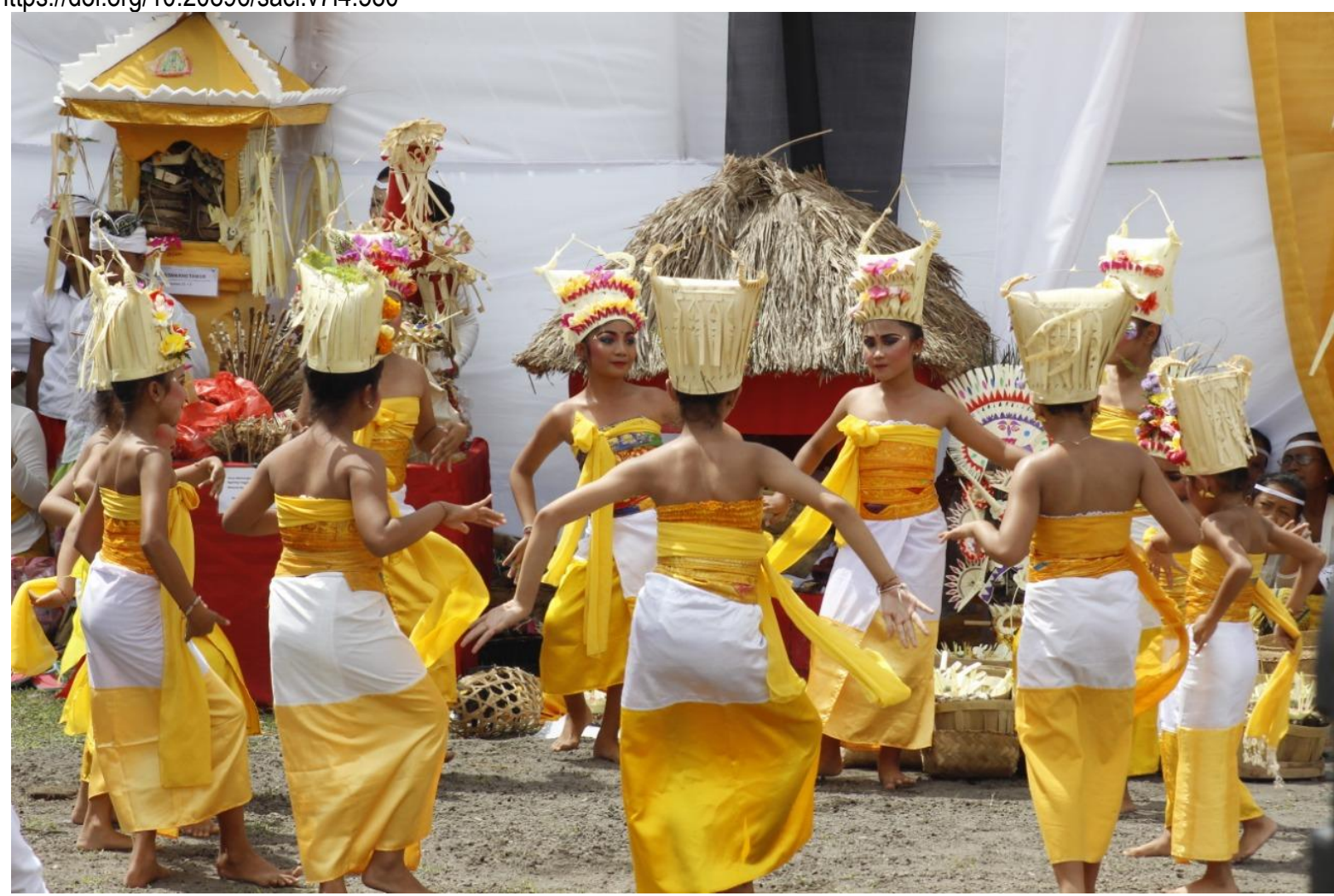

Figure 1: The Rejang Renteng Dance (Rejang Dewa)

Source: Taken by Dedik Cahyendra Kutuh as a Collection of Masceti Temple, 2018

Before the young girls performed the Rejang Renteng dance (Rejang Dewa), they were required to be purified through the procession of the purification ceremony. When the God residing at the temple (Ida Batara) arrived at a building located at the middle yard known as bale Panggungan, the holy bathing place (beji) ceremony started. It is believed that God bathes here. The procession of young girls who voluntarily took part is locally known as Banten Pemendak (welcoming offering), who offers segehen agung (a type of offering) led by the priest (Jero Mangku) of Masceti. In the purification ceremony held for the children dancers, they are supposed to perform natab banten Byakala, prayascita and durmengala. These activities symbolises the angels descending from heaven to the earth. In this case, the Rejang Renteng dance performed by the children is referred to as the sacred dance
(Tari Wali). After the welcoming (upacara pemendak) and purification ceremony (upacara penyucian) are completed; the dancers dance with graceful movements reflecting that they themselves are the Goddesses descending to the earth; receives a warm welcome. Then these dancers would move around the Bale Panggungan (this movement is also called murwa daksina), holding a thread (locally known as oncer) and move to the right (this movement is called purwadaksina) and are then accompanied by the gong kebyar gamelan orchestra. These simple dancing movements symbolise the cosmic movements with nature's sacred energy where Gods reside, has, and are descended as the dancing movements.

The Rejang Renteng dance (Rarejangan) performed by the housemakers (Figure 2) were performed at the village hall yard. 


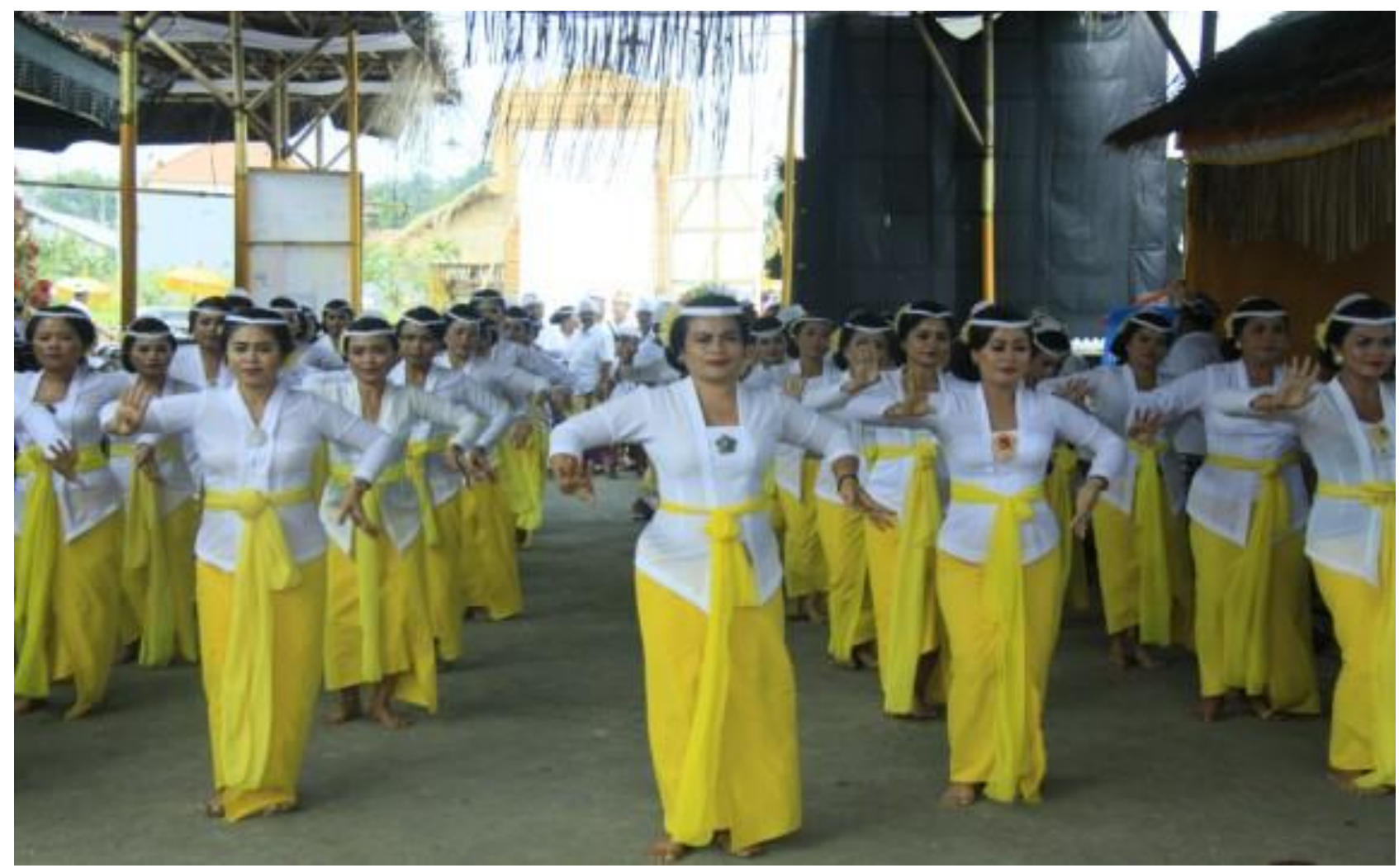

Figure 2

Source: Taken by Dedik Cahyendra Kutuh as a Collection of Masceti Temple, 2018

Prior to performing the dance, like the children dancers of the Rejang Renteng dance (Rejang Dewa), these homemakers too went through the process of purification ceremony; however, the purification process took place at the outer yard where they performed the dance. Unlike the inner yard, where the children performed the Rejang Renteng dance is considered sacred; the outer yard of Besakih Temple, where the homemakers performed the Rejang Renteng Dance (Rarejangan) is not considered sacred. Hence, no particular purification ritual involving the activity of natab Byekala, Prayascita Duemengala and Dapetan was held. The only ritual, which is locally known as upakara dampingan rejang ring ajeng was held and performed in front of the shrine).
The Rejang Renteng dance (Rerejangan) was also performed by 200 dancers to welcome the 73rd anniversary of the Independence Day of the Republic of Indonesia at Rendang District, Karangasem (Figure 3).

Figure 4 shows the Rejang Renteng dance (Rerejangan) performed by the homemakers at South Pemecutan village in the form of a competition; nine dancers were sent by each banjar (the smallest unit of neighbourhood under a traditional village) to commemorate the $73^{\text {rd }}$ anniversary of the Independence Day of the Republic of Indonesia, for which no purification ceremony was held. The only ritual, which is locally referred to as Banten Pejati was offered to inform the Almighty God that a great activity would be performed. 


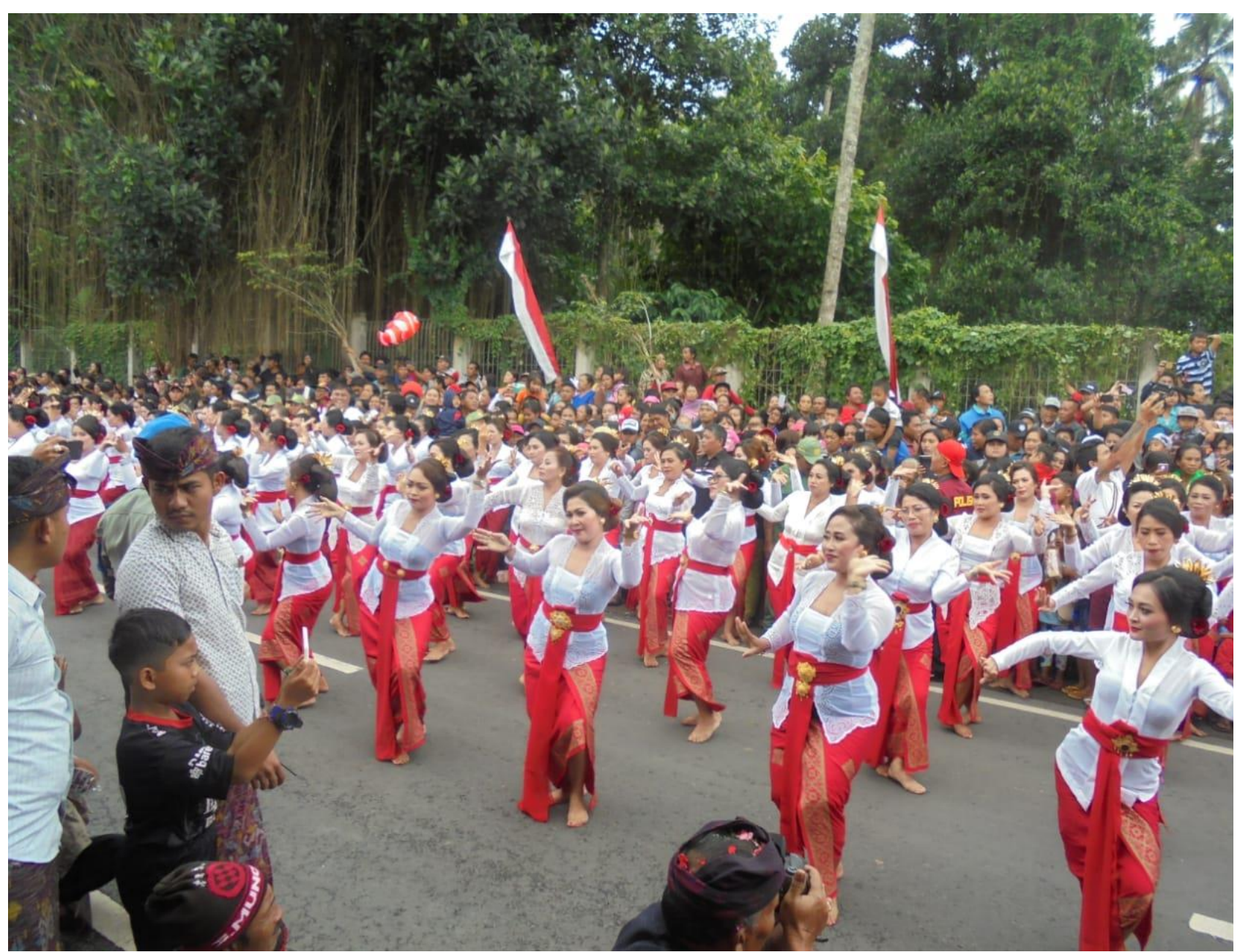

Figure 3: The Rejang Renteng dance Performed by the Homemakers Who Were the Members of the PKK Organisation to Welcome the 73rd Anniversary of the Independence Day of the Republic of Indonesia

Source: Authors, 2018 


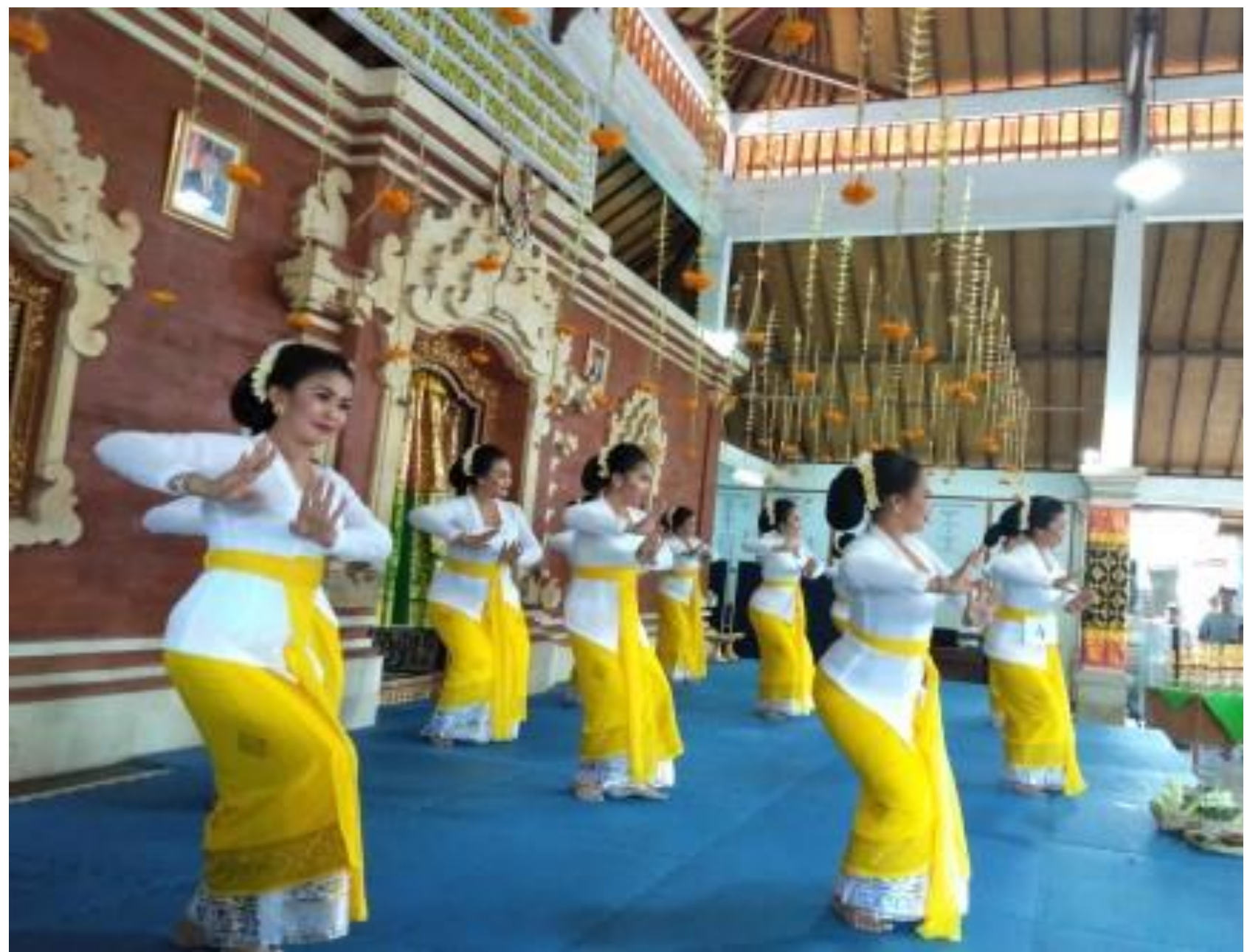

Figure 4: The Competition of the Rejang Renteng Dance at Sumuh, Denpasar

Source: Authors, 2018

\section{The Functions of the Rejang Renteng Dance}

\section{The Religious Function}

The religious function of the Rejang Renteng dance performed by the holy girls (Rejang Dewa) and the one performed by the female priests (Pemangku) who had attained the menopausal stage at Nusa Penida (Rejang Renta) are sacred dances, meaning that they only function as welcoming (penyambutan) dances. They are performed as part of Upacara Pemedek, namely the ceremony performed to welcome Gods (Nuur Ida Betara) in the form of what is locally referred to as Daksina (a type of offering) performed in front of bale panggungan located at the middle yard of the temple where the dances are performed. As already explained above, the dancers symbolise the angels descending from heaven to the earth to welcome the presence of Gods (Dewata Nawa Sanga). The Gods are escorted from the middle yard to the inner yard where they are supposed to reside at Bale Pengaruman during the temple festival. Figure 5 illustrates the Rejang Dewa form.

The Rejang Dewa dance, which is classified as a Sacred dance (Tari Wali) and functions as the worshipping dance, should not be changed into a non-sacred dance with a different function. This is because the Rejang Dewa dance form fulfills the criteria of Satyam, Siwam and Sundaram. In other words, this dance form demonstrates the truth, ethics and beauty (peace). However, the Rejang Renteng dance performed by the homemakers is a seasonal dance; it is innovative and creative and is colossally performed and it is not considered as a sacred dance. Hence, it is not performed either at the middle or inner yard of the temple but in the outer yard of the temple. The reason is that it is performed only for amusement; it does not 
fulfil the requirements of Satyam, Siwam and Sundaram. The sacred Rejang Renteng dance is different from the non-sacred one from the space, time and process points of view. The sacred Rejang Renteng dance symbolises the cosmologic strength visualised as the dancing movements, whereas the non-sacred Rejang Renteng dance is made up of the created movements and only functions as amusement.

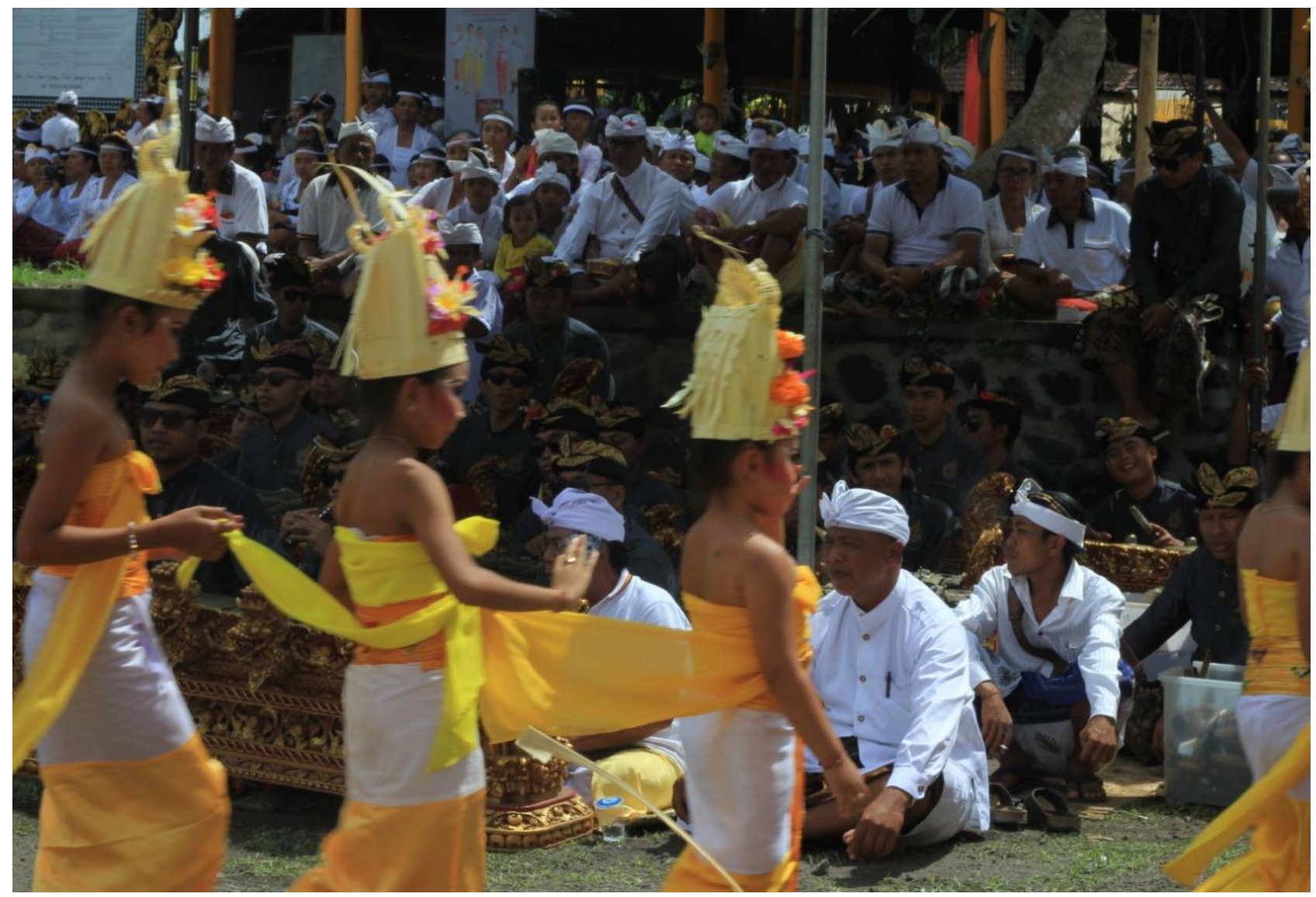

Figure 5: The Dancers of the Rejang Dewa Dance Were Holding What is Known as Oncer Source: The Picture Was Taken by Bangkok, Kutuh, a Collection of the Committee of the Masceti Temple Festival

\section{Social Function}

The Rejang Renteng dance cannot be interpreted from one aspect only. This is because, this dance is a product of the interaction between all the dancers, the gamelan orchestra, the viewers, and so forth and all of them collectively contributes to the meanings it contains.

Therefore, it is clear that the Rejang Renteng dance functions to strengthen social solidarity among people, as illustrated by the competition of the Rejang Renteng dance held at Sumuh, Denpasar. Every Banjar (the smallest unit of neighbourhood) from Delod Puri village, South Denpasar, sent the homemakers as it had to commemorate the 73rd anniversary of the Independence Day of the Republic of Indonesia. Being the winners was not the objective of the participants, but the uniform dancing rhythms of the dancers complemented by the uniform costume the dancers wore, and importantly, high aesthetic value.

\section{The Art and Culture Maintenance Function}

According to Yasa (2018:1), art refers to the product of what is created, tested and intended by a human; it is poured through the mind into a work. Therefore, everybody requires art in their life and needs to maintain and preserve all the existing artworks. Bandem (1996:9) affirms that in Bali, almost no religious ceremony is stated to 
have been completed without the performing art (dance). The arts are not only performed for the Hindu religious ceremonies (temple festival), but they are also performed in almost every activity of the Balinese people. Seemingly, in relation to the preservation of the arts and culture, one of the performing arts which should be preserved is the Rejang Renteng dance. It is a heritage from the ancestors and its values are of high significance as far as the temple festival is concerned. The Rejang Renteng dance (Rejang Dewa) will never get extinct in Bali as long as the Balinese people adhere to its values and significance.

The arts and culture in general and the Rejang Renteng dance in particular, as a cultural heritage from the ancestors, can be preserved by training the homemakers in every banjar in Bali similar to the steps taken in Negara, Gianyar, Tabanan, Denpasar municipalities alongside Badung, Lampung and Surabaya. The dance has been developed not only in Bali but outside Bali as well. Logically, the attempts to maintain and preserve the Rejang Renteng dance have been massively made. Such attempts have been in line with the Act No. 5/2017 in relation to promotion of culture. The issuance of such an Act strengthens the position of the Rejang Renteng dance as far as the context of the Balinese cultural strategy to encounter the current digital civilisation is concerned. In this way, the dance can be sustainably transformed into the seasonal Renteng Rejang dance.

\section{The Meanings of the Rejang Renteng dance}

The meanings of the Rejang Renteng dance can be divided into the theological aesthetic, which are described as follows:

\section{The Theological Meaning}

Similar to the theologies of the other religions, the Hindu theology believes in the existence of the Almighty God (Ida Sang Hyang Widhi) who cannot be thought of or imagined. Neither human nor holy people and gods know who the Almighty God (Ida Sang Hyang Widhi) is, as stated in Bhagavadgita X.2:246 as follows: na me viduá sura-gaóàá prabhavaý na maharûayaá, aham àdir hi devànàý maharûióàý ca sarvaúaá, meaning 'neither gods nor great poets (åûi) know where I come from, as I am the source of every god and priest and everything'(Pudja, 2005:79).Kleúo 'dhikataras teûàm avyaktàsaktacetasàm, avyaktà hi gatir duákhaý dehavadbhir avàpyate. (Bhagavadgita XII.5:311), meaning 'It is more difficult for those who concentrate their thoughts on the Intangible as it is difficult for the creatures with the physical bodies (the physical awareness) to reach the Intangible' (Pudja, 2005 : 93).

Donder (2006:113) claims that although the Almighty God (Ida Sang Hyang Widhi) cannot be thought of and seen, human beings need to have a relationship with Him. To this end, methodologically, Hindu theology has two types of theological typologies. Those who are not bound to the physical awareness can apply what is referred to as the theology of Nirguna Brahma, worshipping the intangible Ida Sang Hyang Widhi (the Almighty God). Those are still bound tothe physical awareness can apply the theology of Saguna Brahma, namely Ida Sang Hyang Widhi (the Almighty God) who can be imagined. In the Saguna Brahma Theology, it is stated that there are several ways of worshipping Ida Sang Hyang Widhi (the Almighty God), one of which is that the Almighty God can be worshipped as a lord who acts as a great and authoritative king with full of love. In this case, Ida Hyang Widhi (the Almighty God) is invited to be worshipped by human beings for His blessings. What was described above is affirmed by Catra (2014: 2728) who states that in Bali, where most people are Hindus, different attempts are made to be close to God through His different manifestations. The religious practices are carried out through what is referred to as "karmasandyasin" and "yoga sandyasin", which lead to the cultural wealth which is dynamically growing and developing. The art of singing holy songs (tembang/kidung), the performing arts, and the percussion arts get united into such a ritual dramatic unity as a cultural expression that people are motivated to be voluntarily involved in and respect it by surrendering themselves and thanking the Almighty God and always proposing for His protection and guidance. 
It is this offering which has inspired the appearance of the performing arts performed for religious purposes (the sacred 'wali' performing arts and the ones performed for amusement 'the bebali performing arts) in religious rituals ...". Similarly, the Rejang Renteng (Rejang Dewa) is also performed as an offering to make human beings close to their God. In this case, as described above, the dancers performing it symbolise the angels descending from heaven to the earth to welcome the presence of God 'Ida Batara' (Dewata Nawa Sanga) at the temple festival. In Usana Bali, according to Panji (1971:4), it is stated that when Lord Indra attacked Mayadenawa, the Bali Aga King, after he was killed in a war, all Gods gathered at Manukraya to meet Lord Indra. At that time, Gods built four Kahyangan temples (the three main temples which a traditional village in Bali should have) at Kedisan, Tihingan, Manukraya and Kaduhuran. After the temples were completed, a festival was held at Manukraya in which the angels performed the Rejang dance, the male ones performed the Baris dance, the Gandarwa played the gamelan instruments such as the flute, the two-stringed musical instrument (rebab); which is alsocalled slonding. The Gods also danced with their respective style. It is reckoned that the Manukraya temple festival lasted for three days. After the festival was completed, the Gods and Goddesses went home to Jambudwipa, followed by the angels and the male sprites (WidyadaraWidyadari) and the Gandarwa. Since then, whenever there is a temple festival, the Rejang dance, the Baris dance, and the Pendet dance are performed. At several villages, it is performed by small girls who wear the crown made of the young coconut leaves (busung).

\section{The Aesthetic Meaning}

Granoka (1998:15) classifies the Hindu aesthetic concepts into three forms (tiga wisesa). They are (1) Satyam which refers to the pure type of the created product; (2) Siwam which refers to the process of how holy the art product is; and (3) Sundaram which refers to the art product which can be enjoyed from the beauty point of view. The tiga wisesa concept is intended to reach the metaphysical and aesthetical spaces to be able to observe carefully the soul that is washed away by the beauty which, according to Mardiwarsito (1986:310), is referred to as langö in the Kawi or Old Javanese language. Putra states that “... Human beings, as the aesthetic creatures, who have the same image as gods (dewa), always want and attempt to present beautiful things." From the term sundaram in the concept of tiga wisesa, it can be clearly seen that Hinduism cannot be separated from the elements of beauty artistically packaged (Putra, 1987, p. 23). In short, the aesthetic meanings of the Rejang Renteng dance performed as part of the temple festival include: banten (offering), location, movements, make-up, and gamelan as described as follows.

\section{Banten (Offering)}

According to Wiana (2007: 46-54), banten (offering) has several symbolic meanings; they are (1) banten pinaka raganta twi, meaning that banten marking human beings physically and spiritually; (2) banten pinaka warna rupaning Ida Bhatara, meaning that banten symbolises the God's Omnipotence; (3) banten pinaka anda bhuwana, meaning that banten signaling the universe. The things symbolised by banten are relevant to what is stated in Bhagavadgita IV.24 :121 as follows:

brahmàrpaóaý brahma havir brahmàgnau brahmaóà hutam, brahmaiva tena gantavyaý brahma-karma-samàdhinà. (Bhagavadgita IV. 24) artinya;'Yang dipuja adalah Brahman (Tuhan), persembahan itu sendiri adalah Brahman (Tuhan), yang mepersembahkan adalah Brahman (Tuhan), oleh Tuhan persembahan itu dihaturkan ke dalam api Brahman (Tuhan), Tuhan adalah sesuatu yang harus dicapai oleh siapa saja yang berharap dapat merealisasikan Tuhan dalam perbuatannya (Pudja, 2005 : 31).

Based on what is stated in Bhagavadgita above, the form of Banten (offering) exemplifies what is offered by human beings as their thanks to the Almighty God (Ida Sang Hyang Widhi Wasa). It can also be stated that Banten is the real form used to express human self-surrendering. Relevant to what is stated in Bhagavadgita above is that what is offered should be 
offered on leaves; your body should be offered on flowers; your holy mind should be offered on fruits; your spirit riped by your spiritual meditation should be offered on the tears resulting from your happiness". In other words, Banten is not prepared to feed ghosts and demons as stated by others.

Banten symbolises the expression of devotion to the Almighty God (Ida Sang Hyang Widhi Wasa); it is an offering to Him; it is not possibly offered as one likes; it should be arranged and organised in such a way that it looks beautiful. The leaves, flowers, fruit and water picked from trees are not directly offered at the temple; they should be rearranged and reorganised in such a way that they will form the type of Banten based on its function and imbued by Sradha (philosophy) and Bhakti (devotion). Banten is full with such an outpouring of beauty that its form cannot be separated from the deep artistic and aesthetical values, meaning that it is made with a full sincere sense.

\section{Location}

The Rejang Renteng dance (Rejang Dewa) is performed in the middle yard of the temple when the welcoming ceremony is carried out. The God residing at the temple is proposed to be seated in what is called as Pengaruman (a type of building in the temple). The Hindus believe that the middle yard and inner yard are the sacred parts of the temple; therefore, they are the proper places where the sacred dances (the Wali and Bebali dances) are performed. According to Soedarsono (in Yasa, 2018:2), the ritual performing arts are characterised by: "... the need for the location where the sacred dances are usually performed ...". The reason is that although the Almighty God (Ida Sang Hyang Widhi) cannot be thought of and seen, human beings need to have a relationship with Him accordingly (Donder, 2006:113). Therefore, methodologically, Hindu theology has two types of theological typologies. Those who are not bound to the physical awareness may apply the Nirguna Brahama theology, namely worshipping the Almighty God (Ida Sang Hyang Widhi) who cannot be imagined. However, those who are still bound to the physical awareness can apply the Saguna Brahma theology, namely worshipping God who can be imagined.
In the Saguna Brahma theology, the Almighty God (Ida Sang Hyang Widhi) is believed not to mind being present at the place intended by $\mathrm{His}$ worshippers and He adjusts Himself to the place prepared by His worshippers. Therefore, it is believed that the Almighty God (Ida Sang Hyang Widhi) can change Himself based on the place already prepared. That is the cycle of the Saguna Brahma theology as far as the Rejang Renteng dance (Rejang Dewa) and the Rejang Rente performed at the middle yard, and inner yard of the temple is concerned. However, the Rejang Renteng dance performed by the homemakers is not bound to the place where it is performed.

\section{Movements}

According to Dibia (1979:4), the variations of movements are the motives or types of movements made in a dance. The Balinese dances can be classified into two dancing movements, namely-

- The pure and meaningless dancing movements; these movements are made to create artistic formations but they are not intended to reflect anything. In other words, the movements are made without taking anything into consideration and what is important is the beautiful movements only. The pure movements are featured by the graceful but meaningless movements made using the hands, head, feet and all the limbs.

- The meaningful movements are the movements which are changed into the meaningfully beautiful movements. In other words, such movements are made to reflect certain things apart from beauty. The Rejang Renteng dance teaches self-control as can be seen from the movement repeated three times. This dancing movement with a slow speed reflects an always controlled action; besides, it also reflects controlling mind and action quietly aimed at a better direction.

The movements made in the Rejang Renteng dance performed for the temple festival (Karya) are as follows: 
- The pepeson movement which includes the steps taken to go forward (mejalan) in which the dancers move gracefully (ngumbang, ngegol) as if they were flying down from the heaven to the earth;

- The pengawak movement which includes what is referred to as the nyalud movement in which the dancers dance as if they were calling things repeatedly, watching and observing the condition and situation in which the ceremony is performed thoroughly;

- The pengecet movement which reflects what is referred to as the praktiaksa behaviour, namely the behaviour of paying attention to and observing the condition and situation of nature and what it contains and 4 . The pekaad movement which is the movement which reflects the phenomenon of nature and everything it contains, the interrelationship between nature and what it contains (human beings) as nature's management.

\section{The Make-up}

The profoundly simple make-up worn by the dancers of the Rejang Renteng dance reflects beauty, causing the dancers to be interested in performing it. Apart from that, the make-up is worn on the face, head, and the outfit also shows the value of beauty. According to Bandem et al. (1985:7), the dancers of the Rejang dance usually wear the traditional costume, golden flowers on the head based on the traditional costume of each region. However, according to Yasa (2018:2), the dancers of the Rejang dancewear a specific costume; the upper part is white, and the lower part is yellow. The white signals being clean, and the yellow signifies being holy.

\section{The Gamelan Orchestra}

Donder (2005: 184-189), based on the theory of wave mechanics, concludes that the gamelan is not played as amusement only. Its inclusion contains several deep meanings. The theory of wave mechanics assumes that: a) the atoms behaving as oscillator produces electromagnetic waves characterised by the wave frequency; b) the energy is not carried by the wave itself but by the photon of which the flowing speed is supplied by the intensity of the wave itself; $c$ ) the speed of the wave emitted by the oscillators determine the probability of the photon emitted by its source.

The gamelan sounds are believed to be composed based on the roars in the foundation of the earth referred to as Prakempa. The roars spread all over the world; therefore, they are referred to like the sounds of pangider bhuana (the earth surrounding sounds), which, in the theory of the creation of nature, are referred to as dentuman besar (big bang). In the holy book of Veda, the sounds indicating the creation of nature are referred to as Nada Brahman or the Om sound whose vibration and resonance have been eternalised up to now in the ether. Such a sound was composed (reconstructed) by Bhagawan Wiswakarma into two groups of sounds; they are the laras pelog group and the laras selendro group. The former symbolises Lord Kama Jaya or masculinity and the latter symbolises Goddess Kama Ratih or feminine. If the laras pelog gamelan is hit, then it will produce the following tones: dang, dung, deng, dong, and ding, and if the laras salendro gamelan is hit, then it will produce the following tones: ndong, ndeng, ndung, ndang, and nding. The sound produced by every blade of the gamelan instruments actually signifies what is referred to as nyasa or the symbol of one of what is known as ista dewata. When the blades of the gamelan instruments are hit, then all the ista dewata_all over the world will react (respond) to the sounds produced. Essentially, every blade of the gamelan instruments is identical with the telephone number in one of the ista dewata. In short, actually gamelan is a high-level technology implementing Hindu theology.

\section{Conclusion}

The Rejang Renteng dance has significantly changed. It can only be performed by girls and women who do not menstruate any longer as it is believed that they are religiously purified. Apart from being believed that they are religiously purified; they are also obliged to take 
part in the purification ritual known as the mejaya-jaya ritual. The Rejang Renteng dance, which is also referred to as the Rejang dewa dance, is also classified as the sacred dance (tari wali) which can only be performed by nine dancers or an odd number of dancers. In addition, it is performed to complete the welcoming ritual (upacara pemendak) where the dancers symbolise the angels descending from the heaven to the earth to welcome (memendak) and direct (menuntun) the Gods descending from the heaven to be present at the temple festival (upacara piodalan) performed by the Hindus. It is performed in the central yard before a building known as Bale Pepelik when the welcoming ritual is held. The dancers move to the right circling the Bale Pepelik three times (this activitiy is known as murwadaksina). The dancers go from the central yard to the inner yard holding what is called oncer (thread) to request the Gods to be seated at another building known as Bale Pengaruman.

The form, function and meaning of the rejang renteng dance have changed. From the form point of view, it used to be only performed by young girls or women who did not menstruate any longer; therefore, it is referred to as the sacred dance (tari wali), but now it has been performed by the homemakers, who are the members of the PKK organisation and are not religiously purified any longer. In addition, they are not obliged to take part in the purification ritual; therefore, this form of the Rejang renteng dance is referred to as the secular dance (the non-sacred dance). It is only performed to amuse those who come to be present at the temple festival. It is not performed to welcome and direct the Gods. It is performed as a part of the anniversary of the establishment of an organisation and to welcome the respected guests such as the president, the political figures, the governor, the regent and so forth; even it is performed for a competition. Therefore, this form of the Rejang dance is called rarejangan, namely the Rejang renteng dance, which is created by the artist inspired by the rejang renteng dance or rejang dewa.. It does not symbolise the angels descending from heaven to the earth. The homemakers, who perform it, have the opportunity to decorate and amuse themselves after being busy with the household chores. In short, not every form of the Rejang Renteng dance is classified as the sacred dance (tari wali). Whether it is classified as the sacred one or not is highly dependent on its form, function and meaning, Satyam, Siwam and Sundaram.

\section{References}

Bandem, I. M. (1996). Etnologi Tari Bali. Yogyakarta: Penerbit Kanisius.

Bandem, I. M., Dibia, I. W., \& Saba, I. G. (1985). Pengembangan Tari Bali. Denpasar: Akademi Tari Indonesia.

Catra, I. N. (2015). Tinjauan Aspek Seni Joged Pingitan dan Baris Upacara. In KESENIAN SAKRAL: Tari Joged Pingitan dan Baris Upacara (pp. 27-46). Denpasar: Listibiya Provinsi Bali.

Dibia, I. W. (1978). Tari Wali Sang Hyang, Rejang, dan Baris. Denpasar: Provinsi daerah Tingkat I Bali.

Donder, I. K. (2005). Esensi Bunyi Gamelan Dalam Prosesi Ritual Hindu. Surabaya: Paramitha.

Donder, I. K. (2006). Brahmavidya: Teologi Kasih Semesta \& Kritik Terhadap Epistemologi Teologi, Klaim Kebenaran, Program Misi, Komparasi Teologi, Dan Konversi. Surabaya: Paramitha.

Frosh, S. (1991). Identity crisis: Modernity, psychoanalysis and the self. Macmillan: International Higher Education.

Granoka, I. W. (1998). Memori Bajra Sandhi: perburuan ke prana jiwa: perburuan seorang Ida Wayan Granoka. Denpasar: Sanggar Bajra Sandhi bekerjasama dengan PT. Seraya Bali Stle.

Littlejohn, S. W. (2009). Teori Komunikasi Edisi 9. Jakarta: Salemba Humanika.

Mardiwarsito, L. (1986). Kamus Jawa Kuno Indonesia. Ende: Nusa Indah.

Pandji, G. B. (1971). Mengungkap Tarian-Tarian Sakral Dan Provan Yang Ada Di Bali. Denpasar: Proyek Pemeliharaan Pengembangan Kebudayaan Daerah Bali. 
Pudja, G. (2005). Bhagavadgita. Surabaya: Kebudayaan Kementerian Pendidikan dan Paramita.

Kebudayaan.

Putra, I. G. (1987). Sejarah Perkembangan Sztompka, P. (2007). Sosiologi Perubahan Sosial. Agama Hindu di Bali. Denpasar: Pemerintah Jakarta: Prenada.

Daerah Tingkat I Bali.

Wiana, I. K. (2007). Tri Hita Karana Menurut

Sedyawati, E. (2010). Budaya Indonesia. Jakarta: Konsep Hindu. Surabaya: Paramitha.

Rajagrafindo Persada.

Yasa, I. K. (2018). Seni dan Agama. Tabanan:

Suteja, I. M. (2017). Balai Pelestarian Nilai Pustaka Ekspresi.

Budaya Bali. Jakarta: Direktorat Jenderal 